\title{
The Dark Side of the Online Learning for Hotel Recreation: The Students Voice on the Perspectives and Challenges
}

\section{Quah Wei Boon, Siti Zaitun Suid}

To Link this Article: http://dx.doi.org/10.6007/IJARBSS/v11-i12/11380

DOI:10.6007/IJARBSS/v11-i12/11380

Received: 05 October 2021, Revised: 08 November 2021, Accepted: 30 November 2021

Published Online: 13 December 2021

In-Text Citation: (Quah \& Suid, 2021)

To Cite this Article: Quah, W. B., \& Suid, S. Z. (2021). The Dark Side of the Online Learning for Hotel Recreation: The Students Voice on the Perspectives and Challenges. International Journal of Academic Research in Business and Social Sciences, 11(12), 1134-1148.

\section{Copyright: (c) 2021 The Author(s)}

Published by Human Resource Management Academic Research Society (www.hrmars.com)

This article is published under the Creative Commons Attribution (CC BY 4.0) license. Anyone may reproduce, distribute, translate and create derivative works of this article (for both commercial and non0-commercial purposes), subject to full attribution to the original publication and authors. The full terms of this license may be seen at: http://creativecommons.org/licences/by/4.0/legalcode

Vol. 11, No. 12, 2021, Pg. $1134-1148$

Full Terms \& Conditions of access and use can be found at http://hrmars.com/index.php/pages/detail/publication-ethics 


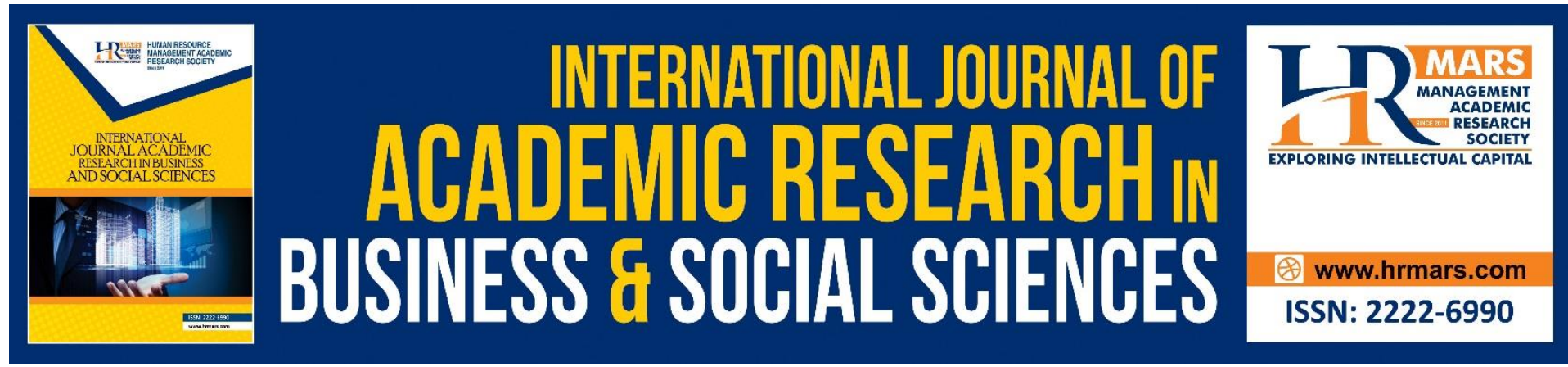

\title{
The Dark Side of the Online Learning for Hotel Recreation: The Students Voice on the Perspectives and Challenges
}

\author{
Quah Wei Boon, Siti Zaitun Suid \\ Unit Hotel Operation, Sungai Petani Community College, 08000 Kedah, Malaysia \\ Email: skyman823000@yahoo.com, sitizaitunsuid@gmail.com
}

\begin{abstract}
This study was conducted to identify the implementation of online learning for Hotel Recreation subject among Sungai Petani Community College students. A qualitative study involving 15 students was conducted to determine the students' views on the implementation of online learning for The Recreation Hotel subjects. The open-ended question was conducted together with all participants to collect information on the main content lime which consists of: i) the views of the students; ii) the implementation of learning; iii) constraints and challenges; iv) suggestions for improvements in the implementation of online learning as well as v) students' satisfaction towards the implementation of online learning. Feedback from all participants was translated and analyzed according to the theme. The findings show that more than half of students have opinions related to challenges to the implementation of online learning. Nevertheless, students acknowledge that lecturers have successfully implemented online learning for the subject, even though lecturers face various challenges. The mentioned challenges are unstable Internet problems, insufficient Internet data, inability to carry out practical activities, lack of suitable recreation equipment, many assignments that need to be completed, and difficulty in understanding online learning for the subject. In addition, students have contributed several suggestions to improve all challenges that arise, including providing video reference materials for each activity, conducting outdoor activities that follow the Standard Operating Procedures (SOPs), and providing Internet facilities at the college. In conclusion, most students are satisfied with implementing online learning for Hotel Recreation.
\end{abstract}

Keywords: Unstable Internet Problems, Insufficient Internet Data, Google Classroom, Google Meet, Online Learning

\section{Introduction}

The spread of the Covid-19 Pandemic, which occurred early in 2020, has shocked the world and is no exception in Malaysia; thus, the first case was recorded in January 2020. It is caused by a Chinese national infected with the Covid-19 Pandemic who has entered Malaysia through Singapore. The new virus and disease are the most recently discovered coronavirus, and the World Health Organization (2020) has declared the disease as Pandemic until the Pandemic begins in Wuhan, China, in December 2019. 
On 18 March 2020, the honorary Prime Minister of Malaysia announced the Movement Control Order (MCO). Since then, almost all Public Institutions of Higher institutions (PHEI) and Private Institutions of Higher Institutions (PHEI) have implemented online learning concepts. Sungai Petani Community College (KKSP) is one of the institutions that has been ordered to close with the MCO. Therefore, there are changes in the learning system where it is implemented online or virtually. It presents new challenges to students and lecturers, which greatly impacts new teaching methods.

This online learning method (e-learning) has been used in tandem with the development of the internet network. Virtual or online learning is almost identical to the normal learning implemented where it involves two-way communication between students and lecturers, but what sets it apart is that there are no physical and face-to-face encounters, instead only meeting through virtual spaces such as through the Google Meet, Google Classroom, Microsoft Team, Webex applications and so on. In addition, monitoring and evaluation by lecturers are also carried out as usual. Following the Covid-19 Pandemic that has plagued Malaysia to date, online learning has continued to be expanded until 2021, as stated by the Ministry of Higher Education. However, various challenges need to be studied and addressed by all parties in applying this online learning.

\section{Problem Statement}

In line with the current development of education, various applications and technologies play a very important role in online learning. Sungai Petani Community College is also affected by this situation, but Google Meet, Google Classroom, Microsoft Teams and other applications are online applications preferred by KKSP lecturers in implementing the curriculum syllabus for Dec 2020. However, there are challenges and constraints for some modules that need to perform physical or practical activities; as stated by Gillett-Swan (2017), online learning is difficult to move learning beavering into a "real world" context, while Venkataraman (2020) states that high bandwidth or strong internet connectivity requires online courses, and many students are not provided. Furthermore, the International Labour Organization (2020) indings have shown that people cannot practice their skills in the workplace or laboratory to the extent that e-learning is insufficient. Therefore, a study should be conducted to determine the extent of students' perspectives on the implementation of online learning for the subjects of Hotel Recreation.

\section{Research Objectives}

1. To understand students' perspectives on the implementation of online learning for Hotel Recreation subject.

2. To understand the implementation of online learning for Hotel Recreation subject from student response.

3. To understand the constraints or challenges students face when attending online learning classes for the Hotel Recreation subject.

4. To understand the students' recommendations, expect colleges to support lecturers implementing online learning for Hotel Recreation.

5. To understand students' satisfaction with the implementation of online learning for the Hotel Recreation subject. 


\section{Literature Review}

\section{Google Classroom}

In August 2014, Google LLC launched the Google Classroom app, a free web app for anyone registering with Google. Google Classroom (GC) is a free learning platform for all educators and students to facilitate the most widely used online teaching and learning (OTL) due to the COVID-19 Pandemic where schools have to be closed due to the Movement Control Order (MCO). The e-learning platform has played an important role during the Pandemic, helping schools and universities facilitate student learning during university and school closures, said (Subedi et al., 2020).

The main goal of Google Classroom is to make it easier for lecturers and students to share materials, videos, files or anything else that is important for students' learning. A recent study by Iftakhar (2016) stated that teachers could store all files on Google Drive, make an assessment, or put any link such as YouTube for teaching purposes. From Google Classroom, a teacher can email all students simultaneously. Janzen (2014) shows the benefits of using Google Classroom, which is very easy to use. Google Classroom's design greatly facilitates its use, and instructional options are used to send and track tasks; communication with entire courses or individuals is also simplified through announcements, emails, and notification buttons (Janzen, 2014).

Google Classroom is a learning management system that makes it easy for lecturers to plan, disseminate, and evaluate lessons and enable students to learn online or remotely. Google Classroom is very helpful for lecturers in learning management, can save time, keep classes organized, and improve communication with students. As Crawford (2015) says, everyone can access it with Google Apps for Education, among the free productivity range of tools including Gmail, Drive, and documents.

Iftekhar (2016) says teachers also use Google Classroom when universities need it. Students believe that this platform is beneficial because they can easily access learning and learning materials. After all, it breaks traditional classroom physical and temporal limitations.

Lecturers can use the Google Classroom platform for effectiveness OTL for assignments, class management, and communication with students. In addition, Google Classroom is also the platform of choice for virtual and increasingly popular classrooms. This virtual learning also indirectly promotes paperless learning.

Google Classroom promotes paperless learning by requiring lecturers to upload all learning resources, including notes, videos, quizzes, and assignments, to Google Drive. Students can also read the information provided and submit completed assignments without printing them. Google Classroom also facilitates effective, paperless online collaboration between students and teachers. Teachers can easily generate online discussions or send various online learning activities. Students can also give feedback or clarify a specific topic with their classmates and virtual teachers (Alim et al., 2019). Before that, Azhar and lqbal (2018) demonstrated that Google Classroom had an insignificant impact on teaching and learning strategies, but it helped simplify basic documentation and class management.

Google Meet

The use of Google Meet (GM) is a method introduced by the Department of Polytechnic and Community College Education (JPPKK), but there are various digital applications or 
applications used in addition to Google Meet, i.e., Google Classroom, Zoom, Microsoft Teams, Webex, and so on. Google Meet is a free online conferencing and video call service that anyone with a Google account can hold meetings or classes. Google Meet (GM) has many advantages over other apps where teachers can use it for virtual learning. According to Ismail (2020), OTL will not be a complicated issue.

Online teaching and learning are all activities that involve students and teachers using an online digital platform to conduct teaching and learning (T\&L) sessions (Jafar et al., 2020). The Sungai Petani Community College, especially lecturers and students, need to do home teaching and learning to avoid being left behind and ready for the tests. Normally, video conferencing or online classes a free app is a great way to get the job done. Google Meet is a free online conferencing and video call service that anyone with a Google account can hold meetings or classes. The advantages of GM will certainly satisfy the needs of educators in delivering its teaching as it is also an alternative media application for T\&L processes that can be featured on Android applications, web applications and even iOS.

Since the COVID-19 Pandemic has spread worldwide; as a result, some online video conferencing software or online meetings, such as Google Meet, are popular options for staying connected at work. Google Meet, also known as Google Hangouts Meet. Unwilling to do so, the COVID-19 Pandemic that has hit the world has provided widespread benefits and wisdom to educators in the efforts of teachers to explore the benefits of today's existing information technology by applying their creativity and abilities (Hamat et al., 2020). Andrew et al (2020); Arias et al (2018) have done comparative research between online learning and face-to-face learning, finding that implementing online $T \& L$ is cheaper.

Students who can't take GM classes online have the opportunity to watch the recording at any time. With GM's advantage, then the efforts of teachers will not be like pouring water onto the leaves but can ensure that every student is not left behind in education. The GM platform has become a new norm that needs to be applied in the daily work routine for most people, especially lecturers.

Constraints or Challenges in Implementing Online Learning

Despite the many advantages of online teaching and learning, there are still difficulties or limitations when implementing them. Among the problems or constraints students face is that not all students have access to a good internet network. Therefore, the online T\&L procedure was completely unsuccessful. One of the reasons students will be in trouble with the online T\&L model is that students may come from locations where internet coverage is weak. Google Classroom or Google Meet will be difficult to navigate when lecturers and students have limited internet signals.

In addition, not all students can afford to purchase advanced electronic devices or easy to use to browse Google Meet and Google Classroom. The results come as students do not have good internet access, enough internet data, or appropriate digital tools to come together in learning. Students are inaccessible through Google Classroom, still challenging in our context. This claim is supported by a study conducted by Sepyanda (2018), who stressed that most students would not have smart gadgets and network access at home for elearning. The findings also fit the work of Hebebci et al (2020), who claim that the lack of adequate data plans and infrastructure raises negative opinions on online learning. Therefore, Hassan et al 
(2020) suggested that relevant stakeholders ensure the availability of smart tools and network connectivity for effective teaching and learning through Google Classroom.

Hotel Recreation Subject

The subject of Hotel Recreation is a module that will be studied by students of the Certificate of Hospitality Operations (SOP) at Sungai Petani Community College in semester 3. Recreation is a well-planned activity that is done to occupy leisure time and no element of competition but aims to gain pleasure, peace of mind and relaxation. Learning in the Subject of Hotel Recreation includes exposure to the types of positions available in the Recreation Department in a hotel, identifying recreational facilities offered, learning the management of recreation counters, the development of creative ideas in marketing hotel recreational products and services, and learning basic safety and first aid techniques. For the topic of Introduction to Hotel Recreation, students will be educated with the positions available at the Recreation Department and the tasks for each post. All information regarding jobs at the recreation department will also be shared with students, and eventually, students can distinguish each position and its duties. Next, students will also be exposed to indoor and outdoor games, where students need to indicate all outdoor and indoor activities such as water and extreme activities and include traditional games. In this topic, in addition to knowing the Standard Operation Procedure (SOP) of each activity or game, students also need to know how to store and coordinate game tools. Usually, students will perform activities outside the college such as jungle trekking, hiking, badminton or other activities that cannot be carried out in college. Students are required to implement SOPs for any activities for practical assessment tests. In addition, among the skills for first aid topics, module lecturers or external instructors should also be demonstrated first to students before students implement them in the classroom. To strengthen the T\&L process, students need to do practical training to master a skill taught. For the subject of Hotel Recreation is allocated 4 hours of meetings per week.

\section{The Use of Google Classroom and Google Meet in Hotel Recreation Classes}

Figure 1 shows a screenshot of Google Classroom usage for the Hotel Recreation class for Dec 2020. Lecturers will upload notes for each sub-topic in the Hotel Recreation subject to make it easier for students to understand the topic. In addition, lecturers can also upload videos related to the topics learned to expose students and ensure that students can understand the topic before entering practical classes. Lecturers can also upload quiz questions, assignments, and projects here on the Google Classroom platform. The students will also upload all the assigned assignments to Google Classroom. Apart from Google Classroom, one of the platforms used is Google Meet, where virtual face-to-face meetings with students are conducted. Through Google Meet, students will have class lectures as usual in the classroom. Light exercise and practical activities such as activity management and first aid will also be implemented virtually. 


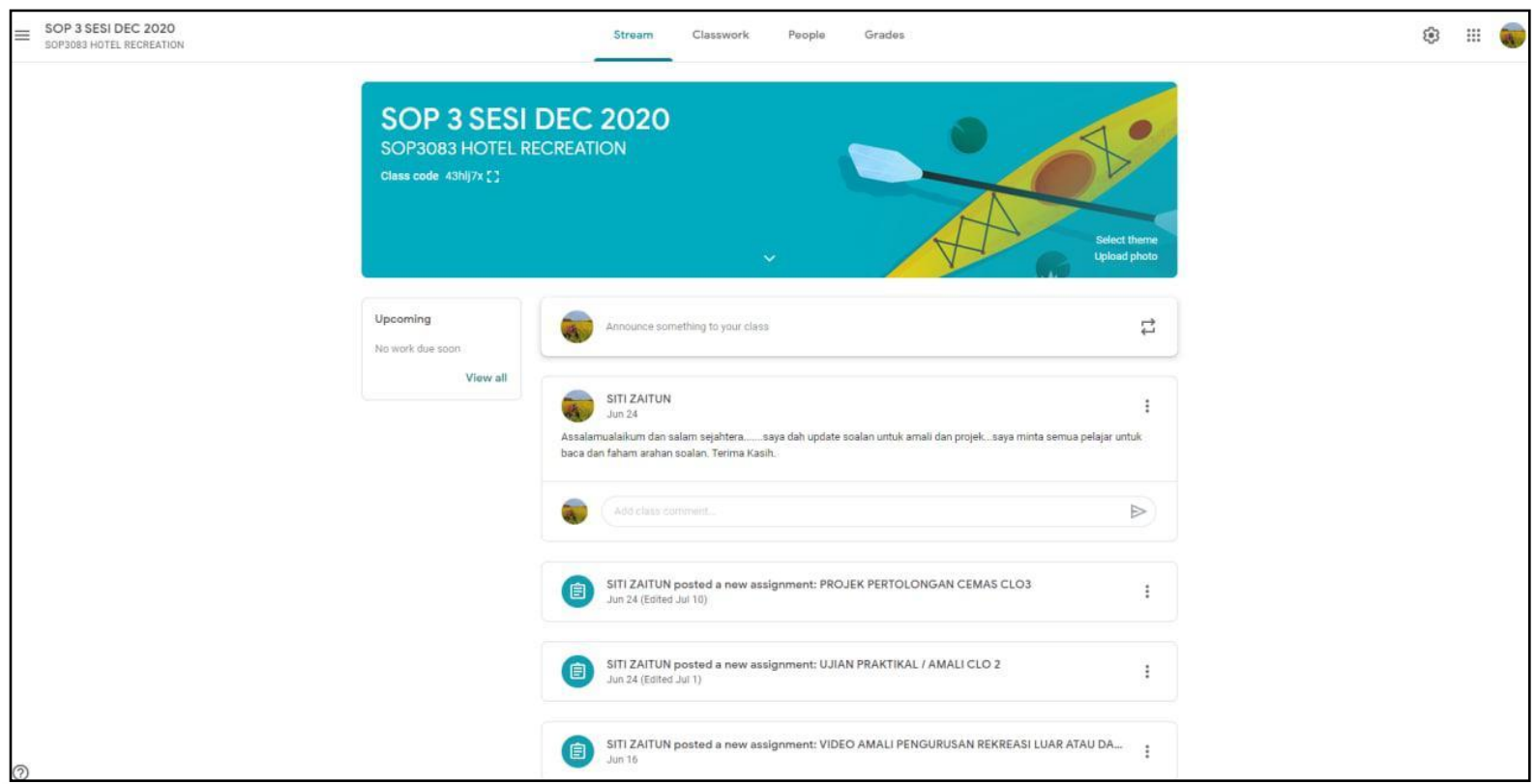

Fig. 1 Google Classroom screenshot for Hotel Recreation subject

Figure 2 shows the screenshot when implementing the student's final project, the First Aid Basic Course, via Zoom Meeting. This learning is theoretical and practically carried out by qualified instructors. After the course project is completed, the student must send a written report directly to Google Classroom. Once a student has submitted either a report, a video production assignment, or answered a quiz, the lecturer will identify whether a student has submitted it late or did not submit it. In addition, lecturers can also review assignments and provide feedback directly to students through this platform. Among the advantages of using Google Classroom, students can save on printing tasks or reports and save time and make it easier to send assignments to lecturers.

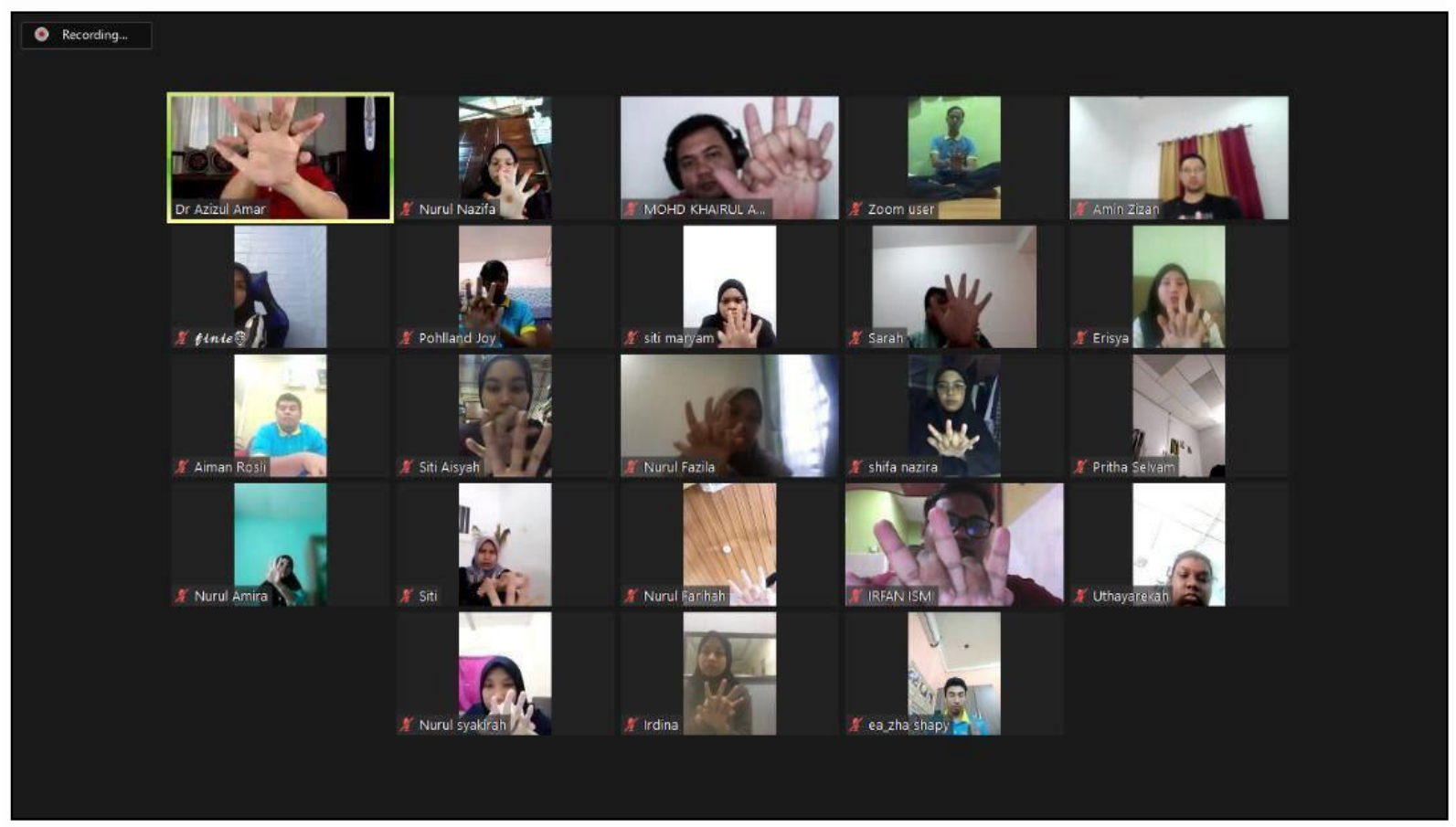

Fig. 2 Students implement the final project, First Aid Basics Course, through the Zoom Meeting platform 
Figure 3 is a screenshot in Google Classroom when a student submits a video recording assignment for which it has replaced the practical assessment that should have been performed face-to-face in college Students also need to be creative and innovative during this video production because, at that time, the Enhanced Control Order (EMCO) was being implemented. Therefore, with the equipment constraints in which many stores do not operate. The Google Classroom platform becomes a platform for collecting all forms of assignments and quizzes students have sent. It also becomes easy for students to make references and review all information that has been stored there.

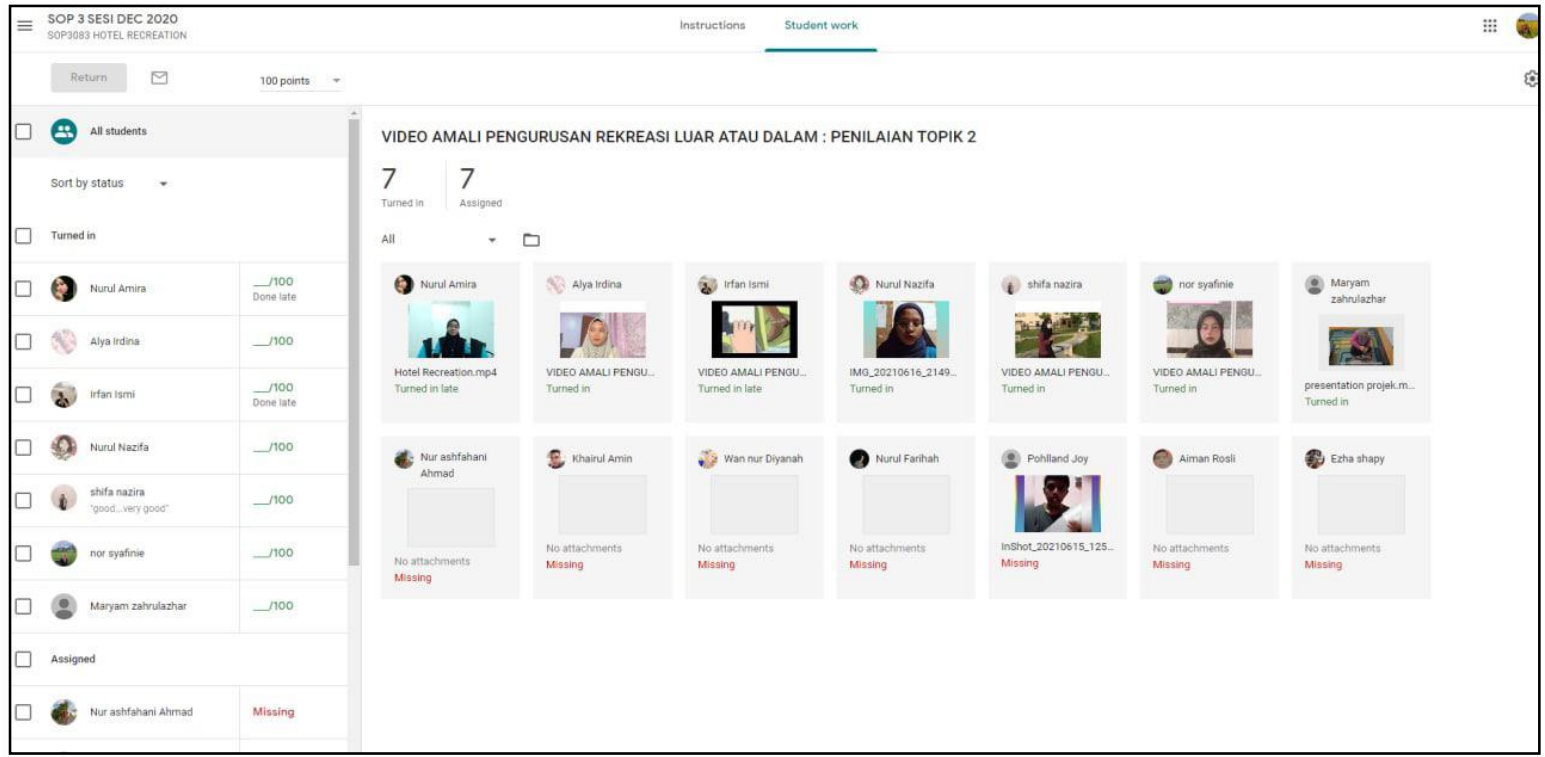

Fig. 3 Screenshot in Google Classroom when students submit video recording assignments

\section{Methodology}

This study is based on the methodology of qualitative research. The study involved 15 Sungai Petani Community College students during the Dec 2020 session that took the subject of Hotel Recreation. Each respondent was given pseudonym code D1 to D15 to replace their real name to maintain the participants' confidentiality and comply with the study's ethics. Questionnaire methods with open-ended questions have been applied. There are five questions used in the distributed questionnaire, which are in the following list:

Question 1. Explain your thoughts on the implementation of online learning for the Hotel Recreation subject.

Question 2. How far do lecturers implement online learning for students of Hotel Recreation subject?

Question 3. Explain the constraints or challenges you face while taking an online learning class for the Hotel Recreation subject.

Question 4. Explain the suggestions for improvement that you would expect from the college to support lecturers implementing online learning for Hotel Recreation.

Question 5. Overall, are you satisfied with the online learning of the Hotel Recreation subject? Please explain your answer.

\section{Findings}

These findings present all the answers recorded based on open-ended questions asked to the participants. 


\section{Respondents' Opinions on the Implementation of Online Learning for Hotel Recreation Subject}

Respondents contributed their opinions on the implementation of online learning for the subject of Recreation Hotel. Table 1 shows the statements of some respondents to question 1.

Table 1: Respondent's statement regarding the implementation of online learning for Hotel Recreation subject

\begin{tabular}{|l|l|}
\hline Respond & Statement \\
\hline D1 & " learning online is having many challenges." \\
\hline D3 & "It's hard for me because a lot of practice is not just a theory." \\
\hline D4 & "... the implementation of online learning for me is not easy." \\
\hline D5 & $\begin{array}{l}\text { 'For this subject, there are some things that are quite complicated if done } \\
\text { online, but lecturers also provide encouragement and help if the students have } \\
\text { any problems' }\end{array}$ \\
\hline D6 & $\begin{array}{l}\text { 'online learning is quite challenging because they can't do activities outside of } \\
\text { learning...." }\end{array}$ \\
\hline D10 & "... It's a bit difficult because the subject does a lot of outdoor activities. \\
\hline D13 & $\begin{array}{l}\text { "For the subject of the hotel recreation, it is not appropriate to study online } \\
\text { because this subject has a lot to do other than theory". }\end{array}$ \\
\hline D14 & $\begin{array}{l}\text { "In my opinion, it is quite difficult because it is more focused on outdoor } \\
\text { activities..." }\end{array}$ \\
\hline D15 & $\begin{array}{l}\text { "Online learning is quite difficult for students as some students do not have } \\
\text { fast internet data." }\end{array}$ \\
\hline
\end{tabular}

Based on the respondent's statement in table 1, more than half of the respondents (9) have opinions related to the challenges of implementing online learning for Hotel Recreation subjects. The respondents agreed that the implementation of online learning for the Hotel Recreation subject was quite challenging, as stated by D1, D6, which has linked the implementation to the challenges. Referring to D3, D4, D10, and D14, respondents identified the implementation of online learning for the Hotel Recreation subject with difficulties as the hotel recreation subject involved many practical activities and outdoor activities. Respondents also attributed the implementation of online learning for Hotel Recreation subject to inappropriateness, as stated by D13.

On the other hand, a small number of respondents said they quite agreed even though the implementation of online learning for Hotel Recreation subject faced many challenges, but lecturers performed well by giving encouragement and support to students as stated by D5.

\section{B. Implementation of Online Learning for Hotel Recreation Subject}

Regarding question 2, the feedback from respondents has been collected in table 2 . 
Table 2: Respondent's statement regarding the implementation of online learning for Hotel Recreation subject

\begin{tabular}{|l|l|}
\hline Respond & Statement \\
\hline D2 & "Very satisfying because the presentation from the lecturers is very clear." \\
\hline D3 & "Very clear presentation" \\
\hline D4 & $\begin{array}{l}\text { "For lecturers, we're very proud because it's not easy to teach hotel subjects } \\
\text { online, and I understand what the hotel recreation is teaching, even though } \\
\text { it's online, but it's easy for us to understand." }\end{array}$ \\
\hline D5 & "Lecturers perform well in teaching and learning." \\
\hline D7 & $\begin{array}{l}\text { "The lecturers who are performing well in online teaching and learning, but } \\
\text { the understanding for practical is very poor because there are no face-to-face } \\
\text { activities." }\end{array}$ \\
\hline D10 & $\begin{array}{l}\text { "Lecturers have done their best and have provided clear explanations for all } \\
\text { topics and provided a clear explanation to students if they need to do the } \\
\text { chosen activities during online learning." }\end{array}$ \\
\hline D11 & $\begin{array}{l}\text { "Lecturers played an important role even though we couldn't visit hotels, but } \\
\text { lecturers allowed us to learn the basics of first aid online." }\end{array}$ \\
\hline D14 & $\begin{array}{l}\text { "What the lecturers taught us was very effective, and we understood that } \\
\text { although we did not feel the atmosphere of real activity due to the } \\
\text { determination and persistence of the lecturers to show us the real atmosphere } \\
\text { even though via online." }\end{array}$ \\
\hline
\end{tabular}

Based on the respondents' statement in table 2, although most of the respondents realized that the implementation of online learning for the Hotel Recreation subject was not easy, they still acknowledged that lecturers managed to implement online learning for Hotel Recreation subject well as stated by D4, D7, D11, and D14.

The implementation of online learning for the Hotel Recreation subject began in June 2020 as the COVID-19 Pandemic hit the world, including Malaysia. Implementing online learning can be very challenging for some subjects, such as subjects involving recreational activities.

Referring to the D10, D11 and D14 statements, more than half of the respondents said they were very satisfied with the implementation and delivery of the lecturers because even though they could not conduct the recreational activities outside.

\section{Constraints or Challenges Faced by Students when Attending Online Learning Classes for Hotel Recreation Subject}

The feedback for this question has been categorized according to themes consisting of:

1. Internet access

2. Unable to perform practical outdoor activities;

3. Lack of suitable equipment;

4. Many assignments need to be completed;

5. Difficulty in understanding online learning class

\section{i. Internet access}

When discussing the implementation of online learning, Internet access has often been mentioned. Respondents have stated internet access in two aspects: i) The Internet 
connection is unstable and ii. insufficient Internet data. Table 3 shows participants' feedback on Internet access in online learning for the Hotel Recreation subject.

Table 3: Respondent's statement to internet access while attending online learning classes for Hotel Recreation subjects

\begin{tabular}{|l|l|}
\hline Respondents & Statement \\
\hline D1 & "... experiencing an internet connection problem..." \\
\hline D2 & $\begin{array}{l}\text { "Poor internet access makes it difficult for me to understand what } \\
\text { lecturers explain." }\end{array}$ \\
\hline D3 & "Internet problems are always a distraction." \\
\hline D4 & "Data problems or Wi-Fi that disrupt learning time" \\
\hline D5 & $\begin{array}{l}\text { "Limited internet data, especially if classes and schedules started early in } \\
\text { the morning until the evening." }\end{array}$ \\
\hline D11 & "Disruption line in residential areas" \\
\hline D12 & "Low Internet accessibility rates.... and relatively high data purchases" \\
\hline D14 & "Internet constraints occur where we live." \\
\hline
\end{tabular}

The findings in table 3 have shown that more than half of the total respondents have encountered unstable Internet constraints resulting in them not concentrating in class. Referring to the D2 statement, the respondent stated that poor Internet access made it difficult to understand what the lecturer had explained. In addition, Internet outages in housing flocks are also a problem faced by respondents, as stated by D11 and D14. Meanwhile, two respondents, D5 and D12, noted that the constraints or challenges faced when attending online learning classes for Hotel Recreation subject are limited Internet data and relatively high data purchases. Thus, some classes and schedules are packed from early to the evening, which leads to increased data consumption.

ii. Unable to perform practical outdoor activities

Hotel Recreation is a subject that involves a lot of outdoor activities. When the implementation of this subject has shifted from face-to-face learning to online learning, the respondent will face constraints or challenges while pursuing online learning for the Hotel Recreation subject.

Table 4: The respondent's statement about being unable to perform practical activities while attending online learning classes for the Hotel Recreation subject

\begin{tabular}{|l|l|}
\hline Respondents & Statement \\
\hline D6 & "Unable to do outdoor activities and unable to do leisure activities." \\
\hline D7 & "can't do any outdoor activities." \\
\hline D9 & "Students are unable to perform full tasks. e.g., camping and hiking." \\
\hline
\end{tabular}

The subject of Hotel Recreation is a module that carries out many outdoor activities outside the college such as jungle trekking, hiking, camping and others. However, when these subjects need to be implemented online, the constraints students face - as in statements D6, D7 and D9 - cannot perform outdoor activities. With these constraints, the student cannot experience the real experience while studying the subject.

iii. Lack of suitable recreation equipment

Equipment is an important element to enable students to practice while attending online learning classes for Hotel Recreation. However, students are not provided with enough 
equipment and are suitable when attending this class. Without adequate and proper equipment, students consider online learning for the Hotel Recreation subject difficult. Table 5 shows the respondents' opinions on the lack of appropriate equipment for online learning for the subject of Hotel Recreation.

Table 5: Respondent's statement regarding the lack of appropriate equipment when attending online learning classes for Hotel Recreation subject

\begin{tabular}{|l|l|}
\hline Respondents & Statement \\
\hline D13 & $\begin{array}{l}\text { "When doing practice or doing the assignment using the video there, it's } \\
\text { quite challenging because there is no equipment or material related to the } \\
\text { hotel." }\end{array}$ \\
\hline D14 & $\begin{array}{l}\text { "don't have the desired activities equipment and the equipment we can't } \\
\text { get" }\end{array}$ \\
\hline
\end{tabular}

D13 noted that no hotel-related equipment or materials would make it difficult for him to complete practice or assignments using video. These indicate that J13 could not complete the assignments given by the Recreation Hotel lecturers properly and completely due to the lack of equipment obtained. The D14 statement also shows that the displeasure of the required equipment will make it difficult for students to complete their assigned assignments.

iv. Many assignments need to be completed

Assignment for the Hotel Recreation subject is a practical and project assessment. Once the implementation of this subject has shifted from face-to-face learning to online learning, practical tests need to be recorded. The number of assignments will increase when lecturers ask students to record each assignment.

Table 6: Respondent's statement regarding many assignments that need to be completed while attending online learning classes for Hotel Recreation subjects

\begin{tabular}{|l|l|}
\hline Respondents & Statement \\
\hline D10 & $\begin{array}{l}\text { "Students need to record videos, and simultaneously, students need to } \\
\text { complete assignments from other subjects." }\end{array}$ \\
\hline
\end{tabular}

v. Difficulty in understanding OTL

Table 7: Respondent's statement regarding the difficulty of understanding OTL while attending online learning classes for Recreation Hotel subjects

\begin{tabular}{|l|l|}
\hline Respondents & Statement \\
\hline D15 & "I don't understand what I'm taught." \\
\hline D11 & "The lecturer's presentation is less clear." \\
\hline
\end{tabular}

\section{Suggestions for improvement for the implementation of online learning for Hotel Recreation subjects.}

The majority of respondents stated that the implementation of online learning for Hotel Recreation subjects could be improved on several points, namely: the provision of reference materials in the form of videos for each activity, conducting outdoor activities that follow the Standard Operating Procedures (SOP) that have been set when conditions have been allowed and providing Internet connectivity for students who have problems with Internet access. 


\section{E. Student Satisfaction with the Implementation of Online Learning for Hotel Recreation Subjects}

Most students are satisfied with implementing online learning for Hotel Recreation subjects. However, there are only two dissatisfied respondents:

"I am not satisfied because when the lecturers taught, I did not understand and lacked the knowledge that the lecturers had conveyed." (D13)

\section{Discussion}

Students showed positive views about the implementation of online learning for Hotel Recreation subjects, although nine (9) respondents gave opinions related to challenges. Thus, the lecturers have performed well by providing encouragement and support to students. Among the challenges faced were i. Internet access; ii. Unable to carry out practical outdoor activities; iii. Lack of equipment; iv. Many tasks need to be completed; and v. Difficulty in understanding online learning. While most respondents realized that online learning for Hotel Recreation subjects was not easy, they still acknowledged that lecturers managed to implement online learning for Recreation Hotel subjects well. Thus, the subject involves many activities outside the college, such as jungle trekking, hiking, camping, etc. Even lecturers have tried to explain to the students.

This study shows that students must face challenges while pursuing the implementation of online learning for The Recreation Hotel subjects. Students have given several suggestions for improvements to help colleges and lecturers increase student satisfaction. Among them is the need to prepare a video for each activity as a reference to make it easier for students to understand because students are unable to carry out such activities; lecturers should also plan to conduct outdoor activities but must follow the SOPs that have been set so that students can also experience the implementation of outdoor activities, and students also recommend that the college can provide Internet facilities in college if students encounter Internet access at home, students can come to college to get Internet facilities and attend classes online in college. Overall, most students who participated in implementing online learning for Hotel Recreation subjects were satisfied.

\section{Conclusion}

Students face many constraints or challenges when attending online learning classes for Recreation Hotel subjects. Among the challenges are i. Unstable Internet problems; ii. Internet data that does not poke; iii. Unable to carry out practical outdoor activities; iv. Lack of equipment; v. Many tasks need to be completed; and vi. Difficulty in understanding online learning. Efforts must be made to overcome these issues to ensure that students achieve the optimum level of satisfaction in pursuing online learning for Recreation Hotel subjects. It can be concluded that lecturers should strive to provide reference materials in the form of videos for each activity, conduct outdoor activities that follow the established Standard Operating Procedures (SOPs) and provide Internet achievement to improve students' optimal understanding during online learning Recreation Hotel subjects. Recreation Hotel lecturers also need to think creatively and innovatively in implementing online learning for the subject of Hotel Recreation relatively; students can clearly understand the explanation given even online. 


\section{Contribution}

The study's findings contribute to the growing body of literature that online learning can be implemented in any institution; all modules can't conduct online learning. Students pursuing the Hotel Recreation subject, a practical course, cannot do it entirely online because it involves some face-to-face practicals and assessments. However, in this study, students' perceptions towards the implementation of online learning for Hotel Recreation subject are positive as same in the previous study Mut et al (2020). Despite that, Technical and Vocational Education and Training (TVET) educators need to revise the contents, curriculum, and assessments that suit online learning or hybrid/blended learning. These findings are consistent with previous research on online learning challenges, such as Ilias et al (2020), who stated that an unstable Internet connection and insufficient data capacity are two major challenges that contribute to issues related to online learning, and Mut et al. (2020), who stated that Internet speed and quota had an impact on e-learning effectiveness. Furthermore, one of the challenges from this study, which was also observed in a prior study by Yeap et al (2021), was videos and online learning preparation. This issue demonstrates that to conduct online learning or hybrid/blended learning, instructors must devote more time and effort to developing interactive activities that use low Internet bandwidth. As a result, students will not be affected by the internet connectivity issue. And this will increase students motivation and engagement in online/hybrid learning.

\section{References}

Alim, N., Linda, W., Gunawan, F., \& Saad, M. S. (2019). The effectiveness of Google Classroom as an instructional media: A case of State Islamic Institute of Kendari, Indonesia. Humanities \& Social Sciences Reviews 7(2), 240-246. doi:10.18510/hssr.2019.7227.

Andrew, A., Cattan, S., Dias, M. C., Farquharson, C., Kraftman, L., Krutikova, S., ... Sevilla, A. (2020). Learning during the lockdown: Real-time data on children's experiences during home learning. Retrieved from https://ifs.org.uk/uploads/BN288-Learning-during-thelockdown-1.pdf

Arias, J. J., Swinton, J., \& Anderson, K. (2018). Online vs. face-to-face: A comparison of student outcomes with random assignment. E-Journal of Business Education and Scholarship of Teaching, 12(2), 1-23. Retrieved from https://files.eric.ed.gov/fulltext/EJ1193426.pdf

Azhar, K. A., \& Iqbal, N. (2018). Effectiveness of Google Classroom: Teachers' perceptions. Prizren Social Science Journal, 2(2), 52-66. Retrieved from https://core.ac.uk/download/pdf/229345703.pdf

Crawford, A. R. (2015). Google Classroom. Retrieved from http://acrawf41.weebly.com/uploads/3/7/3/2/37321095/a._crawford_emerging_techn ology.pptx

Gillett-Swan, J. (2017). The challenges of online learning supporting and engaging the isolated learner. Journal of Learning Design, 10(1), 20-30. Retrieved from https://files.eric.ed.gov/fulltext/EJ1127718.pdf

Hamat, M., Mahlan, S. B., \& Ch'ng, P. E. (2020). Adaptasi pengajaran dan pembelajaran secara maya dalam kebiasaan baharu semasa pandemik COVID-19. Shah Alam: SIG:eLearning@CS.

Hebebci, M. T., Bertiz, Y., \& Alan, S. (2020). Investigation of views of students and teachers on distance education practices during the Coronavirus (COVID-19) Pandemic. International Journal of Technology in Education and Science, 4(4), 267-282. 
doi:10.46328/ijtes.v4i4.113

Iftakhar, S. (2016). Google classroom: what works and how?. Journal of Education and Social Sciences, 3(1), 12-18. Retrieved from https://jesoc.com/wpcontent/uploads/2016/03/KC3_35.pdf

Ilias, A., Baidi, N., Ghani, E. K., \& Mohd Razali, F. (2020). Issues on the use of online learning: An exploratory study among university students during the COVID-19 Pandemic. Universal Journal of Educational Research, 8(11), 5092-5105. doi:10.13189/ujer.2020.081109

International Labour Organization. (2020). ILO-UNESCO Joint Survey on Technical and Vocational Education and Training (TVET) and skills development during the time of COVID-19. Retrieved from https://www.ilo.org/wcmsp5/groups/public/---ed_emp/--emp_ent/documents/genericdocument/wcms_741973.pdf

Ismail, H. (2020). COVID-19 memangkin perubahan pendidikan. Bernama. Retrieved from https://www.bernama.com/bm/tintaminda/news.php?id=1839515

Jafar, M. F., Amran, Z. A., Mohd Yaakob, M. F., Yusof, M. R., \& Awang, H. (2020). Kesediaan pembelajaran dalam talian semasa pandemik COVID-19. Prosiding Seminar Darulaman 2020 Peringkat Kebangsaan, 404-410. IPG Kampus Darul Aman. Retrieved from https://www.researchgate.net/publication/345893409

Janzen, M. (2014). Hot team: Google Classroom. Retrieved from http://tlt.psu.edu/2014/12/04/hot- team-google-classroom/.

Mut, N. A. I. C., Zain N. M., \& Mohd, M. I. (2020). Challenges and perceptions of e-learning among students in a private institution: A case study in Malaysia. 2020 Sixth International Conference on e-Learning (econf), 166-170. https://doi.org/10.1109/econf51404.2020.9385506.

Sepyanda, M. (2018). Students' attitude toward the use of Google Classroom on translation subject in English Department of FKIP Ummy Solok. English Language Teaching and Research, 2(1), 181-188. Retrieved from http://ejournal.unp.ac.id/index.php/eltar/article/view/102661/101047

Subedi, S., Nayaju, S., Subedi, S., Shah, S. K., Shah, J. M. (2020). Impact of e-learning during COVID-19 Pandemic among nursing students and teachers of Nepal. International Journal of Science and Healthcare Research, 5(3),68-76. Retrieved from https://ijshr.com/IJSHR_Vol.5_Issue.3_July2020/IJSHR0012.pdf

Venkataraman, S. (2020). Problems of online classes International Journal of Academic Research Reflector, 9(6), 1-3. doi:10.6084/m9.figshare.13573550

Hassan, W. A. S., Ariffin, A., Ahmad, F., Sharberi, S. N. M., Azizi, N. M. I., Zulkiflee, S. N. (2020). COVID-19 Pandemic: Langkawi Vocational College Student Challenge in using Google Classroom for teaching and learning (T\&L). International Journal of Advanced Trends in Computer Science and Engineering, 9(3), 3299-3307. doi:10.30534/ijatcse/2020/127932020

World Health Organization. (2020). Novel Coronavirus (2019-nCoV). Retrieved from https://www.who.int/docs/default-source/coronaviruse/situation-reports/20200121sitrep-1-2019-ncov.pdf

Yeap, C., Suhaimi, N., \& Nasir, M. (2021). Issues, challenges, and suggestions for empowering technical vocational education and training education during the COVID-19 Pandemic in Malaysia. Creative Education, 12, 1818-1839. doi:10.4236/ce.2021.128138. 